\title{
Flow Based Enumeration of Plasmablasts in Peripheral Blood After Vaccination as a Novel Diagnostic Marker for Assessing Antibody Responses in Patients with Hypogammaglobulinaemia
}

\author{
Vojtech Thon, Marcela Vlkova, \\ Zita Chovancova, Jiri Litzman and Jindrich Lokaj \\ Department of Clinical Immunology and Allergy, Medical Faculty of Masaryk University, \\ St. Anne's University Hospital, Brno \\ Czech Republic
}

\section{Introduction}

Hypogammaglobulinaemic patients are often started on immunoglobulin substitution therapy before antibody production is adequately evaluated. In such a situation, it is difficult to segregate transferred from antigen-induced specific antibody. Therefore we characterized changes in B-cell subpopulations in hypogammaglobulinaemic patients, including plasmablasts, in peripheral blood by flow cytometry after in vivo antigen challenge. We investigated the specificity of antibody production on the B-cell level by ELISPOT, which is independent of substitution therapy.

Common variable immunodeficiency (CVID) is characterized by low serum levels of IgG, IgA, normal or low levels of IgM and impaired antibody responses after vaccination (Conley et al. 1999). The clinical presentation of CVID includes recurrent respiratory tract infections by encapsulated bacteria, autoimmunity, granuloma formations, enteropathy and increased risk of malignancies. The diagnosis is established by exclusion and elimination of other disorders affecting B-cell differentiation. Although standard treatment include long-term immunoglobulin replacement and antimicrobial therapy, the mortality rate of CVID patients is higher than that of the general population (Chapel et al. 2008; Cunningham-Rundles \& Bodian 1999).

Despite intensive research the immunopathogenesis of CVID has not yet been elucidated. It has been suggested that CVID is caused by defects in T cells, B cells, insufficient T-B cell interactions or impaired signaling required for $\mathrm{B}$ or T-cell maturation and function, but the characterization of the genetic defects remains unclear in the majority of patients. Molecular defects involving mutations in CD19 (van Zelm et al. 2006), ICOS (Grimbacher et al. 2003; Salzer et al. 2004), CD81 (van Zelm et al.), Msh5 (Sekine et al. 2007) and TACI (Castigli et al. 2005; Mohammadi et al. 2009; Salzer et al. 2005) were found in less than $10 \%$ of CVID 
patients (Cunningham-Rundles \& Bodian 1999; Schaffer et al. 2007). CVID, therefore, is a heterogeneous group of patients expected to have multiple etiologies, all sharing similar immunologic and clinical characteristics.

Although the precise pathogenesis of CVID remains unknown, a number of common abnormalities involving peripheral blood lymphocytes were described including differences in the number of naïve B cells (follicular B cells), CD21 low B cells, transitional B cells, nonclass-switched IgM/IgD memory B cells (marginal zone-like B cells) (Klein et al. 1997; Shi et al. 2003; Tangye \& Tarlinton 2009), class-switched memory B cells and plasmablasts (Carsetti et al. 2004; Sanchez-Ramon et al. 2008; Warnatz \& Schlesier 2008; Weller et al. 2004). Specifically, CVID patients have reduced populations of $\mathrm{CD}^{2} 7^{+}$memory B cells (classswitched memory B cells and marginal zone-like B cells) and increased percentages of undifferentiated B cells (immature CD21 low B cells (Rakhmanov et al. 2009) and naïve CD27B cells) associated with impaired class switching (Piqueras et al. 2003; Warnatz et al. 2002) and poor differentiation into plasma cells (Taubenheim et al. 2005) when compared to a control population (Ferry et al. 2005; Litzman et al. 2007).

In addition, a vast array of T-cell abnormalities has been described in CVID patients, including defects in TCR-dependent T-cell activation (Thon et al. 1997), reduced frequency of antigen-specific T cells, impaired IL-2 release in CD4+ $\mathrm{T}$ cells (Funauchi et al. 1995), decreased lymphocyte proliferation to mitogens and antigens (Chapel et al. 2008), lack of generation of antigen-primed $\mathrm{T}$ cells after prophylactic vaccination (Bryant et al. 1990; Fischer et al. 1994; Giovannetti et al. 2007), impaired cytokine production (Fischer et al. 1994; Thon et al. 1997), reduced expression of CD40L on activated T cells (Farrington et al. 1994; Piqueras et al. 2003; Thon et al. 1997; Warnatz et al. 2002), significant decrease in Treg cells in CVID patients with granulomatous manifestations and immune cytopenias (Horn et al. 2009), significant reduction of frequency and absolute counts of CD4+ $4^{+}$cells, percentage increase in $\mathrm{CD}^{+} \mathrm{T}$ cells, decrease in distribution of $\mathrm{CD}^{+}$and $\mathrm{CD}^{+}$naïve $\mathrm{T}$ cells in comparison to healthy controls (Giovannetti et al. 2007; Mouillot et al. 2010). This complex list of T-cell abnormality likely plays a major role in determining the clinical course of CVID patients.

In spite all of these multiple T-cell defects proposed as possible cause of CVID, the classification schemes presently in use are based on functional or phenotypic characteristics of B cells (assessment of immunoglobulin synthesis in vitro and phenotypic subsets of peripheral blood B cells): Bryant British classification (Bryant et al. 1990), Freiburg classification (Warnatz et al. 2002), Paris classification (Piqueras et al. 2003) and the recent EUROclass classification (Wehr et al. 2008). A few authors, however, suggested T-cell phenotyping as an aditional parameter for classifying CVID, and current efforts aim at the definition of combined T and B-cell phenotyping for the classification of CVID (Mouillot et al. 2010; Warnatz \& Schlesier 2008).

Although a lot is known about B cell subsets in of CVID patients, the way their B-cell subpopulations change in response to vaccination compared to normal individuals is largely unknown. Specifically, there are limited data as to antibody responses to protein or polysaccharide antigens and the quantity and quality of antibodies produced by patient from different groups of CVID patients.

We focused on (1) specific in vitro antibody production by individual B cells following vaccinations by T-dependent (protein) and T-independent (polysaccharide) antigens and (2) 
changes of B-cell subpopulation after vaccination in peripheral blood of CVID patients and healthy donors (Chovancova et al. 2011).

\section{Methodological approach}

\subsection{Flow cytometry and assessment of plasmablasts}

Blood samples from examine subjects were collected between 7 and 12 a.m. to exclude diurnal variation of lymphocyte subsets. Lymphocytes and B-cell subpopulations were analyzed directly from peripheral blood or from isolated PBMC (Litzman et al. 2007). The main B cell subpopulations identified in PBMCs were CD21 low B cells characterized as CD21 lowCD38low, naïve $B$ cells $\left(\operatorname{IgD}^{+} \mathrm{CD} 27-\right)$, marginal zone-like $\mathrm{B}$ cells $\left(\operatorname{IgD}^{+} \mathrm{CD} 27^{+}\right)$, switched memory B cells $\left(\mathrm{IgD}-\mathrm{CD} 27^{+}\right)$and plasmablasts $\left(\mathrm{IgD}-\mathrm{CD} 27^{++} \mathrm{CD} 38^{++}\right)$. Cells were identified using monoclonal antibodies (mAbs): FITC-conjugated anti-CD38, PE-conjugated anti-IgD, PE-conjugated anti-CD21, PC5-conjugated anti-IgM (all from Pharmingen International, San Diego, CA, USA) and PC5-conjugated anti-CD27 (Beckman Coulter Miami, $F L, U S A)$. The B-cell subpopulations were analyzed by gating on $\mathrm{CD}^{+}{ }^{+}$cells (PC7conjugated anti-CD19, Beckman Coulter, Marseille, France). Immunophenotyping of B lymphocytes was performed by five-colour cytometry Cytomix FC500 (Beckman Coulter Miami, FL, USA). The relative numbers of CD19+ $\mathrm{B}$ cells are showed as mean $\pm \mathrm{SD}$.

\subsection{Enzyme-linked immunosorbent spot assay (ELISPOT)}

The ELISPOT assay provides both qualitative (type of immune protein) and quantitative (number of responding cells) information (Czerkinsky et al. 1983). We have modified the ELISPOT technique for the detection of specific antibody responses to TET and PPS.

96 wells microtitre plates (MultiScreen ${ }^{T M}-H A$, Millipore Corporation, Billerica, USA) were coated with tetanus toxoid (10 Lf/ml, ÚSOL, Prague, Czech Republic) and PPS $(0.5 \mu \mathrm{g} / \mathrm{ml}$, PNEUMO 23, Sanofi Pasteur, Lyon, France) antigens in carbonate buffer ( $\mathrm{pH}=9.6)$ overnight at $4{ }^{\circ} \mathrm{C}$. Plates were washed 3 times with PBS containing $0.05 \%$ Tween 20 and subsequently incubated for 30 minutes at $37^{\circ} \mathrm{C}$ with $100 \mu$ per well of blocking buffer $(1 \%$ solution of bovine serum albumin in PBS; Sigma Aldrich, Stenheim, Germany). Plates were then stored at 4 ${ }^{\circ} \mathrm{C}$ until use. Peripheral blood mononuclear cells (PBMC), obtained from peripheral blood by gradient centrifugation (Lymphoprep, Axis-Shields PoC AS, Oslo, Norway) were added to the coated microtitre plates in RPMI 1640 medium (Sigma Aldrich) containing 10\% heatinactivated FCS (LabMediaServis, Jaromer, Czech Republic) at 4 different dilutions $\left(1.25 \times 10^{5}\right.$; $2.5 \times 10^{5} ; 5 \times 10^{5}$ and $1 \times 10^{6}$ in $100 \mu \mathrm{l} /$ well for CVID patients and $0.625 \times 10^{5} ; 1.25 \times 10^{5}$; $2.5 \times 10^{5} ; 5 \times 10^{5}$ cells in $100 \mu \mathrm{l} /$ well for controls and cultured overnight at $37^{\circ} \mathrm{C}$ in $5 \% \mathrm{CO}_{2}$. After cells were washed off the plates $100 \mu \mathrm{l}$ /well rabbit anti-human IgG, IgA or IgM conjugated to horseradish peroxidase (Dako Cytomation, Glostrup, Denmark; diluted 1:500 in PBS/Tween) were added to each well and incubated for $1 \mathrm{~h}$ in the dark at room temperature. Plates were washed 3 times with PBS containing $0.05 \%$ Tween 20 followed by the addition of $100 \mu \mathrm{l} /$ well of 3-amino-9-ethylcarbazole substrate solution (AEC, Sigma Aldrich) and incubated for 15 minutes at room temperature in the dark. Plates were rinsed with water and dried overnight at room temperature.

The red-coloured spots were counted with the AID ELISPOT reader (AID, Autoimmun Diagnostika GmbH, Strassberg, Germany). This provided accurate recognition and calculation 
of the spots and allowed objective differentiation between background and "real" spots. The results were expressed as a number of SFC per million B cells.

\subsection{Immunization of subjects}

Thirty-seven patients with established CVID (14 males, 23 females, age range 20 - 74 years) were examined. Twenty-six patients were treated with regular infusions of intravenous immunoglobulin (IVIG), six patients received regular subcutaneous immunoglobulin (SCIG) injections and one patient intramuscular immunoglobulin therapy (IMIG). Four patients were newly diagnosed and not yet on immunoglobulin replacement therapy at the time of the study.

All CVID patients were vaccinated simultaneously with tetanus toxoid (TET) vaccine (ALTEANA, Sevapharma, Prague, Czech Republic) and unconjugated pneumococcal polysaccharide (PPS) antigens (PNEUMO 23, Sanofi Pasteur, Lyon, France), except patient no. 34, who received PPS one year after TET. All patients on IVIG were vaccinated one week prior to administration of replacement therapy.

The control group consisted of 80 healthy individuals. Fifty (16 males, 34 females, age range 22 - 72 years) were vaccinated with TET; ten (4 males, 6 females, age range 15 - 46 years) were given PPS alone; twenty (8 males, 12 females, age range 14 - 50 years) received both TET and PPS. The study was approved by the Ethics Committee of Masaryk University, Brno and signed informed consent was obtained from each participant.

\subsection{Enzyme-linked immunosorbent assay (ELISA) and immunoglobulin quantification}

Commercially available kits were used for measuring specific IgG antibody levels against tetanus toxoid (VaccZymeTM Human Anti Tetanus Toxoid IgG EIA Kit, The Binding Site Group Ltd, Birmingham, United Kingdom) and IgG antibodies titers against IgA (Human Anti-IgA isotype IgG ELISA, BioVendor, Brno, Czech Republic) in serum.

Trough serum levels of immunoglobulins IgG, IgA and IgM were measured in CVID patients prior to the IVIG infusion by nephelometry using the BN2 Nephelometer (Dade Behring, Marburg, Germany) according to the manufacturer's instructions.

\subsection{Statistical analysis}

Data were analyzed using the STATISTICA software [StatSoft, Inc. (2007), STATISTICA (data analysis software system), version 8.0.; www.statsoft.com]. Mann-Whitney U-test and Wilcoxon matched pairs test were used for analyses of dependencies between particular parameters in studied groups; $\mathrm{p}<0.05$ was regarded as statistically significant.

\section{Laboratory findings}

\subsection{Kinetics and optimal timing for detection of specific spot forming cells isolated from peripheral blood after vaccination}

The kinetics of anti-TET (T-dependent) specific antibody production by peripheral blood B cells was tested by ELISPOT assay in healthy volunteers from day 5 to day 9 after antigenic challenge. The same strategy was used in the assessment of anti-PPS (T-independent) 
specific antibody production in healthy controls from day 1 to day 8 after antigen challenge. Day 7 was found to be optimal for the detection of specific antibody producing B-cells in peripheral blood for both antigens and all tested immunoglobulin isotypes (IgG, IgA, and IgM). Our findings are in agreement with previous studies (Kodo et al. 1984; Stevens et al. 1979; Thiele et al. 1982).

\subsection{Kinetics and specific antibody responses against protein (T-dependent) and polysaccharide ( $T$-independent) antigens in healthy individuals}

The group of healthy controls was vaccinated with protein antigen (tetanus toxoid, TET), unconjugated PPS antigens (PNEUMO 23) either separately or in combination. We found no significant difference in the number of SFC (IgG, IgA, IgM) against vaccinated antigens whether they were administered separately or simultaneously (Mann-Whitney U-test, $p$ with range between 0.56 to 0.98 ). The number of specific SFC against both types of vaccines in the cohort of healthy controls is shown in Table 1.

\begin{tabular}{|c|c|c|c|}
\hline & \multicolumn{3}{|c|}{ SFC/106 B cells } \\
\cline { 2 - 4 } & MEDIAN & MINIMUM & MAXIMUM \\
\hline IgG anti-TET & 10371 & 964 & 86747 \\
\hline IgA anti-TET & 532 & 24 & 9707 \\
\hline IgM anti-TET & 0 & 0 & 0 \\
\hline IgG anti-PPS & 3843 & 812 & 76880 \\
\hline IgA anti-PPS & 33935 & 3200 & 186384 \\
\hline IgM anti-PPS & 9540 & 2165 & 52994 \\
\hline
\end{tabular}

Table 1 . The number of spot forming cells against protein $(n=70)$ and polysaccharide $(n=30)$ antigens in a group of healthy controls. SFC $/ 10^{6} \mathrm{~B}$ cells (spot forming cells per million CD19+ B cells); IgG, IgA, IgM anti-TET (IgG, IgA, IgM antibodies specific spot forming cells against tetanus toxoid); IgG, IgA, IgM anti-PPS (IgG, IgA, IgM antibodies specific spot forming cells against pneumococcal polysaccharides)

\subsection{Specific antibody response in subgroups of CVID patients}

CVID patients $(n=37)$ were classified according to the Freiburg (Warnatz et al. 2002) and EUROclass classification (Wehr et al. 2008) (Table 2), allowing a comparative analysis of antibody production and clinical phenotype. As we had expected, the majority of our welldefined CVID patients did not mount a specific humoral immune response against the two vaccines but several patients produced low numbers of vaccine-specific SFC (see below).

As for EUROclass classification scheme, 3 patients of group smB+21 norm $(n=7$, patient no. $18,19,20), 1$ patient of group $\operatorname{smB}+21^{\text {low }}(n=6$, patient no. 13) and 1 patient of group smB$21^{\text {low }}(\mathrm{n}=12$, no. 1$)$ had detectable IgG antibody responses against tetanus toxoid. In group $\mathrm{smB}+21^{\text {low }}$ there was 1 patient (no. 14) who secreted IgM and another patient (no. 12) who formed IgA and IgM antibodies against PPS. The latter patient is the only one among the CVID group who formed specific antibodies of 2 different immunoglobulin isotypes. Regarding the group smB-21 norm $(n=12)$, no specific antibody production was detected. In the Freiburg classification all patients with detectable antibody responses (no. 12, 13, 14, 18, 19 and 20) were from group II the exception (no. 1) being a group Ia patient. 


\begin{tabular}{|c|c|c|c|c|c|c|c|c|c|c|c|c|c|c|c|}
\hline$\ddot{c}$ & 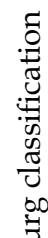 & 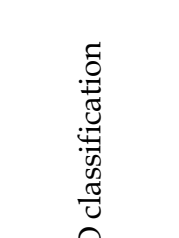 & & & 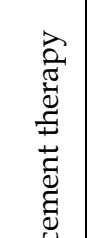 & $\bigcup_{0.0}$ & $\begin{array}{l}\mathbb{L}_{00} \\
0\end{array}$ & $\sum_{0=0}$ & 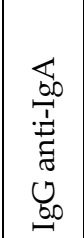 & 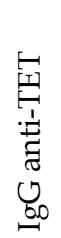 & 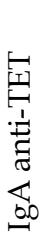 & 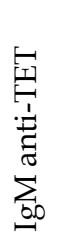 & 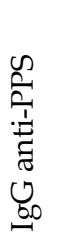 & 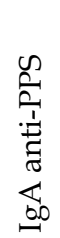 & 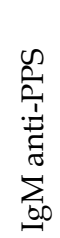 \\
\hline ఏ్ & 完 & 号 & ひ & $\underset{\widetilde{\sigma}}{\stackrel{\Xi}{0}}$ & $\frac{\pi}{2}$ & & $\mathrm{~g} / 1$ & & titer & \multicolumn{6}{|c|}{$\mathrm{SFC} / 10^{6} \mathrm{~B}$ cells } \\
\hline 1 & Ia & smB-21 low & $\mathrm{F}$ & 40 & IMIG & 2.78 & $<0.01$ & $<0.04$ & neg & 344 & 0 & 0 & 0 & 0 & 0 \\
\hline 2 & Ia & smB-21low & $\mathrm{F}$ & 74 & IVIG & 5.39 & $<0.01$ & $<0.05$ & neg & 0 & 0 & 0 & 0 & 0 & 0 \\
\hline 3 & Ia & smB-21low & M & 47 & SCIG & 3.92 & 0.06 & 0.19 & neg & 0 & 0 & 0 & 0 & 0 & 0 \\
\hline 4 & Ia & smB-21low & M & 50 & IVIG & 3.37 & $<0.01$ & $<0.05$ & neg & 0 & 0 & 0 & 0 & 0 & 0 \\
\hline 5 & Ia & smB-21 low & M & 36 & IVIG & 7.35 & $<0.01$ & 0.05 & neg & 0 & 0 & 0 & 0 & 0 & 0 \\
\hline 6 & $\mathrm{Ib}$ & smB-21 norm & $\mathrm{F}$ & 66 & IVIG & 5.82 & $<0.01$ & 0.10 & n. d. & 0 & 0 & 0 & 0 & 0 & 0 \\
\hline 7 & $\mathrm{Ib}$ & smB-21 norm & $\mathrm{F}$ & 34 & no & 2.01 & $<0.01$ & $<0.05$ & neg & 0 & 0 & 0 & 0 & 0 & 0 \\
\hline 8 & $\mathrm{Ib}$ & smB-21 $1^{\text {norm }}$ & M & 30 & IVIG & 5.77 & $<0.01$ & $<0.05$ & neg & 0 & 0 & 0 & 0 & 0 & 0 \\
\hline 9 & $\mathrm{Ib}$ & smB-21 $1^{\text {norm }}$ & $\mathrm{F}$ & 20 & no & 0.66 & $<0.01$ & 0.13 & $1: 50$ & 0 & 0 & 0 & 0 & 0 & 0 \\
\hline 10 & $\mathrm{Ib}$ & smB-21 norm & $\mathrm{F}$ & 44 & IVIG & 3.16 & $<0.01$ & 0.10 & neg & 0 & 0 & 0 & 0 & 0 & 0 \\
\hline 11 & $\mathrm{Ib}$ & smB-21 norm & $\mathrm{M}$ & 55 & IVIG & 5.09 & $<0.01$ & 0.32 & neg & 0 & 0 & 0 & 0 & 0 & 0 \\
\hline 12 & II & $\mathrm{smB}+21^{\text {low }}$ & $\mathrm{F}$ & 71 & IVIG & 6.29 & 0.08 & 0.29 & neg & 0 & 0 & 0 & 0 & 256 & 659 \\
\hline 13 & II & $\mathrm{smB}+21^{\text {low }}$ & M & 19 & IVIG & 4.49 & $<0.01$ & 0.07 & neg & 407 & 0 & 0 & 0 & 0 & 0 \\
\hline 14 & II & $\mathrm{smB}+21^{\text {low }}$ & M & 24 & no & 4.99 & $<0.01$ & 0.20 & neg & 0 & 0 & 0 & 0 & 0 & 104 \\
\hline 15 & II & $\mathrm{smB}+21^{\text {low }}$ & $\mathrm{F}$ & 54 & IVIG & 6.95 & $<0.01$ & 0.15 & $1: 100$ & 0 & 0 & 0 & 0 & 0 & 0 \\
\hline 16 & II & $\mathrm{smB}+21^{\text {low }}$ & $\mathrm{F}$ & 41 & SCIG & 6.14 & $<0.01$ & 0.05 & neg & 0 & 0 & 0 & 0 & 0 & 0 \\
\hline 17 & II & $\mathrm{smB}+21^{\text {low }}$ & $\mathrm{M}$ & 57 & SCIG & 5.66 & 0.02 & $<0.05$ & neg & 0 & 0 & 0 & 0 & 0 & 0 \\
\hline 18 & II & $\mathrm{smB}+21$ norm & $\mathrm{F}$ & 19 & SCIG & 6.75 & 0.05 & 0.75 & neg & 185 & 0 & 0 & 0 & 0 & 0 \\
\hline 19 & II & $\mathrm{smB}+21$ norm & M & 44 & IVIG & 5.91 & 0.22 & $<0.05$ & neg & 713 & 0 & 0 & 0 & 0 & 0 \\
\hline 20 & II & $\mathrm{smB}+21^{\text {norm }}$ & $\mathrm{M}$ & 44 & IVIG & 6.37 & $<0.01$ & 0.10 & neg & 231 & 0 & 0 & 0 & 0 & 0 \\
\hline 21 & II & $\mathrm{smB}+21$ norm & M & 31 & IVIG & 3.80 & 0.02 & 0.07 & n. d. & 0 & 0 & 0 & 0 & 0 & 0 \\
\hline 22 & II & $\mathrm{smB}+21$ norm & $\mathrm{F}$ & 68 & IVIG & 6.35 & $<0.01$ & $<0.05$ & neg & 0 & 0 & 0 & 0 & 0 & 0 \\
\hline 23 & II & $\mathrm{smB}+21$ norm & $\mathrm{M}$ & 59 & IVIG & 6.86 & 0.04 & 0.06 & neg & 0 & 0 & 0 & 0 & 0 & 0 \\
\hline 24 & II & $\mathrm{smB}+21$ norm & $\mathrm{F}$ & 41 & IVIG & 5.26 & $<0.01$ & 0.08 & neg & 0 & 0 & 0 & 0 & 0 & 0 \\
\hline
\end{tabular}

Table 2. Continues on next page 


\begin{tabular}{|c|c|c|c|c|c|c|c|c|c|c|c|c|c|c|c|}
\hline ఫे & 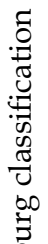 & 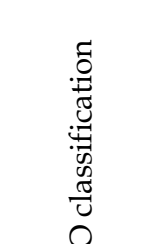 & & & 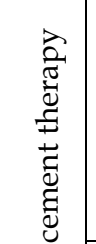 & $\bigcup_{600}$ & $\mathbb{b}$ & $\sum_{000}$ & 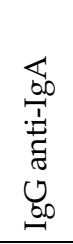 & 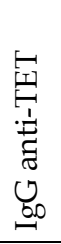 & 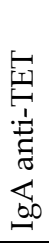 & 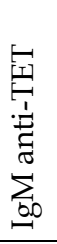 & 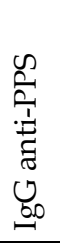 & 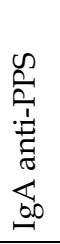 & 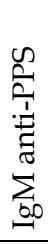 \\
\hline દ્ગ & 离 & 占 & $\underset{\varpi}{ひ}$ & $\underset{\sigma}{\infty}$ & $\frac{2}{2}$ & & $\mathrm{~g} / 1$ & & titer & \multicolumn{6}{|c|}{ SFC $/ 10^{6}$ B cells } \\
\hline 25 & II & smB-21low & $\mathrm{F}$ & 42 & IVIG & 8.15 & $<0.01$ & 0.50 & neg & 0 & 0 & 0 & 0 & 0 & 0 \\
\hline 26 & II & smB-21low & $\mathrm{F}$ & 58 & IVIG & 5.98 & $<0.01$ & $<0.05$ & neg & 0 & 0 & 0 & 0 & 0 & 0 \\
\hline 27 & II & smB-21low & $\mathrm{F}$ & 57 & IVIG & 8.15 & $<0.01$ & $<0.05$ & neg & 0 & 0 & 0 & 0 & 0 & 0 \\
\hline 28 & II & smB-21low & M & 34 & IVIG & 6.21 & $<0.01$ & 0.05 & neg & 0 & 0 & 0 & 0 & 0 & 0 \\
\hline 29 & II & smB-21low & $\mathrm{F}$ & 43 & IVIG & 6.27 & $<0.01$ & $<0.05$ & neg & 0 & 0 & 0 & 0 & 0 & 0 \\
\hline 30 & II & smB-21low & $\mathrm{F}$ & 50 & SCIG & 4.48 & $<0.01$ & $<0.05$ & neg & 0 & 0 & 0 & 0 & 0 & 0 \\
\hline 31 & II & smB-21low & $\mathrm{F}$ & 28 & IVIG & 5.62 & $<0.01$ & $<0.05$ & neg & 0 & 0 & 0 & 0 & 0 & 0 \\
\hline 32 & II & smB-21 norm & $\mathrm{F}$ & 44 & IVIG & 6.75 & -0.01 & 0.05 & neg & 0 & 0 & 0 & 0 & 0 & 0 \\
\hline 33 & II & smB-21 norm & $\mathrm{F}$ & 61 & IVIG & 7.54 & 0.09 & $<0.05$ & neg & 0 & 0 & 0 & 0 & 0 & 0 \\
\hline 34 & II & smB-21 norm & $\mathrm{F}$ & 27 & no & 2.35 & $<0.01$ & 0.45 & neg & 0 & 0 & 0 & 0 & 0 & 0 \\
\hline 35 & II & smB-21 norm & $\mathrm{F}$ & 40 & IVIG & 7.10 & $<0.01$ & 0.09 & neg & 0 & 0 & 0 & 0 & 0 & 0 \\
\hline 36 & II & smB-21 norm & $\mathrm{F}$ & 40 & SCIG & 8.51 & $<0.01$ & $<0.05$ & neg & 0 & 0 & 0 & 0 & 0 & 0 \\
\hline 37 & II & smB-21 norm & M & 19 & IVIG & 7.00 & $<0.01$ & $<0.05$ & neg & 0 & 0 & 0 & 0 & 0 & 0 \\
\hline
\end{tabular}

Table 2. (continued) Results of the ELISPOT assay in group of CVID patients. F (female); $\mathrm{M}$ (male); n.d. (not done); SFC/106 B cells (spot forming cells per million CD19+ B cells); IgG, IgA, IgM anti-TET (IgG, IgA, IgM specific spot forming cells against tetanus toxoid); IgG, IgA, IgM anti-PPS (IgG, IgA, IgM specific spot forming cells against pneumococcal polysaccharides); IgG anti-IgA (IgG antibodies against IgA)

The decreased production of SFC in CVID patients was independent of replacement immunoglobulin treatment: four CVID patients without substitution therapy showed the same defect in the production of SFC and specific antibodies after vaccination as CVID patients on replacement therapy.

\subsection{Changes of B-cell subpopulations in peripheral blood one week after vaccination}

The mean percentage of CD19+ B cells was $11 \pm 4 \%$ in healthy controls and $13 \pm 7.6 \%$ in CVID patients before vaccination. One week after vaccination the percentages were unchanged (12 $\pm 5 \%$ in healthy controls and $13 \pm 6.7 \%$ in CVID patients).

We then examined the changes of absolute and relative numbers of plasmablasts and other B lymphocyte subpopulations in the peripheral blood one week after antigen challenge (Fig. $1,2)$. In healthy controls no statistically significant changes in absolute and relative numbers of switched memory B cells were found between the two measurement time points, before 
a) healthy controls

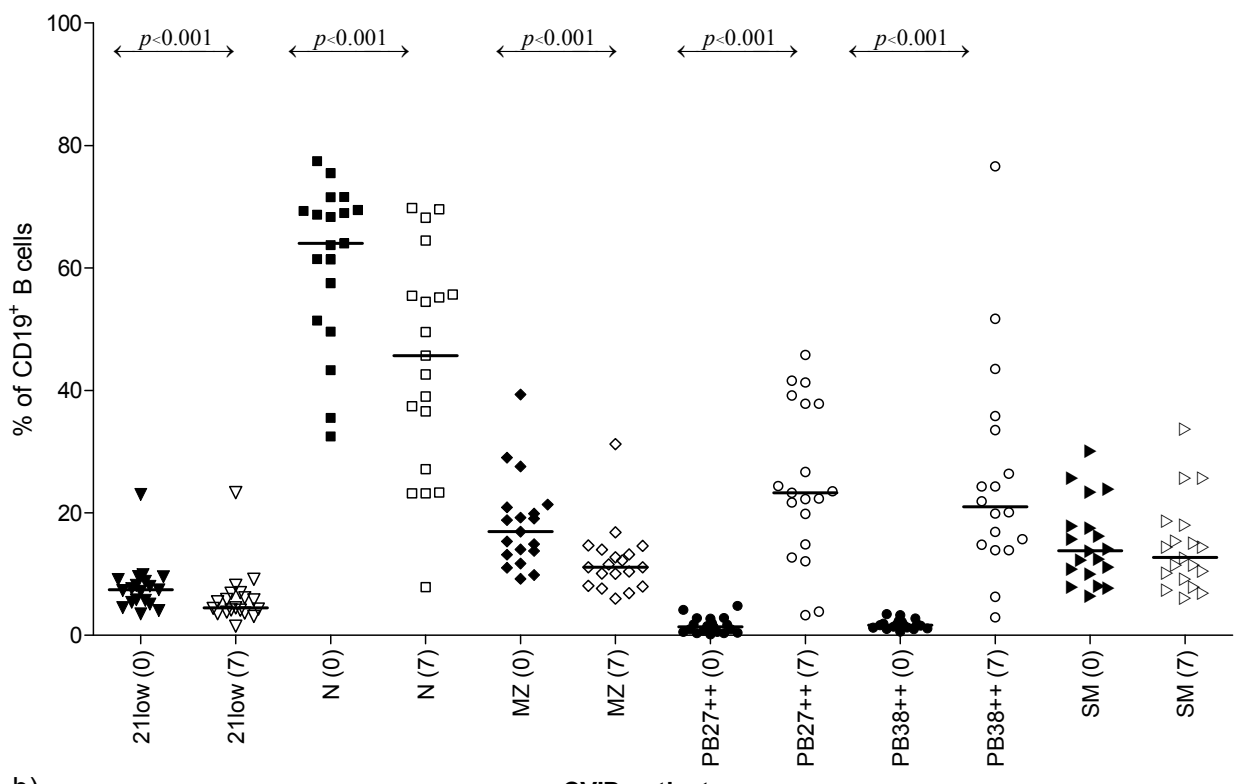

b)

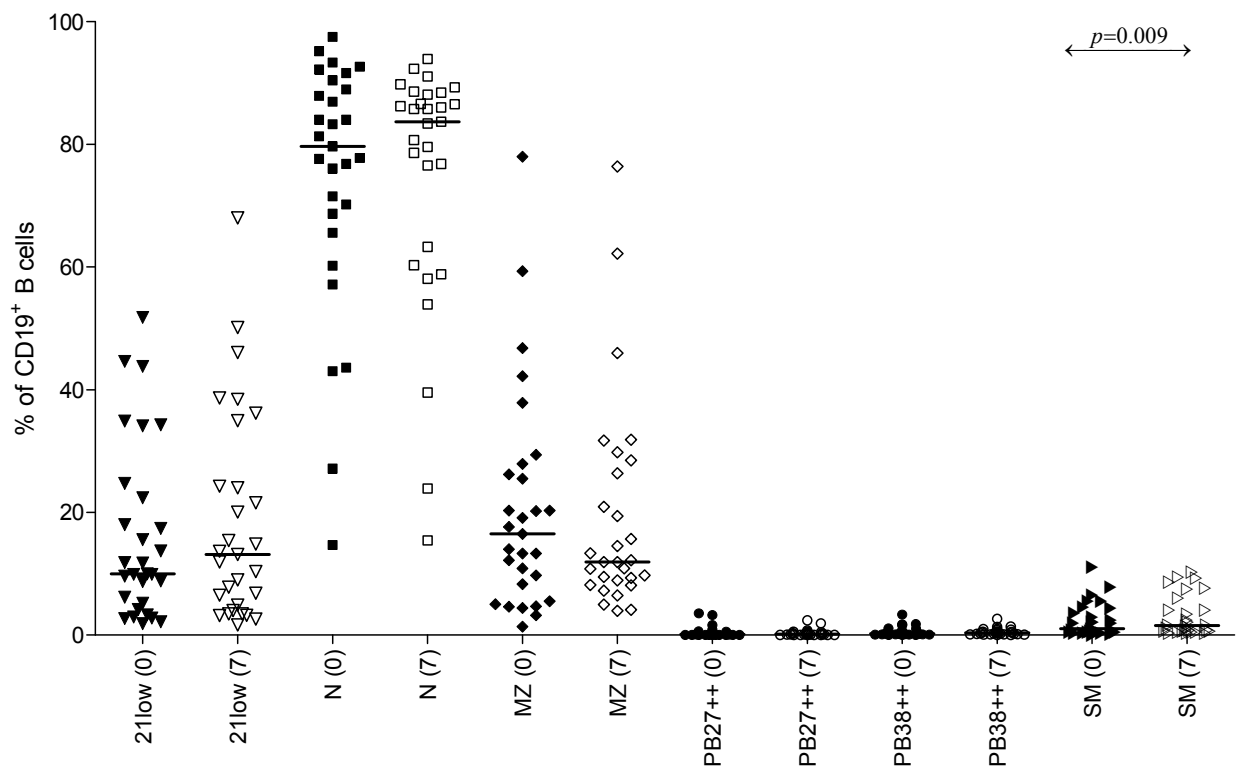

Fig. 1. Changes of relative numbers of B-cell subpopulations in healthy controls $(\mathrm{HC} ; \mathrm{n}=19$; a) and CVID patients (CVID; $\mathrm{n}=29 ; \mathrm{b}$ ) before (0) and one week (7) after antigen challenge. 21 low (CD21 low B cells), N (naïve B cells), MZ (marginal zone - like B cells), PB27++ and $\mathrm{PB}^{++}$(plasmablasts), SM (class-switched memory B cells) 
and one week after vaccination. However, a highly significant increase in absolute as well as relative numbers of plasmablasts gated as IgD-CD27++ $\left(\mathrm{PB} \mathrm{CD} 27^{++}\right)$cells and IgM-CD38++ (PB CD38++) cells ( $\mathrm{p}<0.001$ in both cases) occurred (Fig. 3), while the absolute and relative numbers of CD21 low B cells $(p<0.02)$, naïve B cells $(p<0.001)$ and MZ-like B cells $(p<0.001)$ decreased. In contrast, among the cohort of CVID patients no statistically significant changes of examined cellular subpopulations, including plasmablasts (Fig. 1, 2 and 3) were observed except for a slight increase in $\mathrm{smB}$ cells to a level still well below the levels of healthy controls. This increase was statistically significant in Wilcoxon matched pairs test.

The fact that the number of plasmablasts corresponds with the number of SFC strongly suggest that the examination of peripheral blood plasmablasts on day 7 after vaccination can be used as a surrogate marker for specific antibody responses in normal controls and as a diagnostic procedure to identified CVID and other patients with defect in terminal B-cell differentiation (Chovancova et al. 2011).

\section{Consequences}

\subsection{Hypogammaglobulinaemic patients and diagnostic vaccination}

Poor vaccination responses to protein and polysaccharide antigens is essential for definitionbased diagnosis of CVID (Conley et al. 1999). Quantitative assessment of specific antibody in serum is routinely performed by ELISA assay. However CVID patients are often started on immunoglobulin substitution therapy before antibody production is adequately evaluated. In such a situation, it is difficult to segregate transferred from antigen-induced specific antibody. We have designed a in vitro functional measurement of antibody production on the B-cell level using the ELISPOT technique, which is independent of substitution therapy (Chovancova et al. 2011). In addition, we monitored changes in B-cell subpopulations, including plasmablasts, in peripheral blood by flow cytometry after in vivo antigenic challenge.

The defect in the antibody production and SFC reduction observed in a cohort of CVID patients are not secondary to Ig substitution since the same defects were also seen in four CVID patients before starting Ig replacement therapy. IVIG treated CVID patients were vaccinated exactly one week before administration of immunoglobulin substitution. In this manner the theoretically possible influence of immunoglobulin replacement therapy on the generation of SFC was reduced.

Prior to this study, specific antibody production in substituted CVID patients following vaccination had been evaluated in serum. Goldacker et al. (Goldacker et al. 2007) measured specific antibodies in serum by ELISA assay. The contribution of parallel immunoglobulin substitution on antibody titers was difficult to correct and required a relatively complicated vaccination formula. Based on these calculations the authors reported a decrease in serum antibody levels against T-dependent and T-independent antigens in CVID patients between IVIG infusions. Using a meningococcal polysaccharide vaccine, Rezaei et al. described decreased vaccination response against meningococcal polysaccharide measured in serum of CVID patients while on IVIG (Rezaei et al. 2008; Rezaei et al. 2010). Immunization with a protein neoantigen, e.g. bacteriophage, and investigation of immune response with neutralization assay brought similar results (Ochs et al. 1971). Nevertheless, there is very little quantitative data correlating individual vaccination responses to proposed functional 
a)

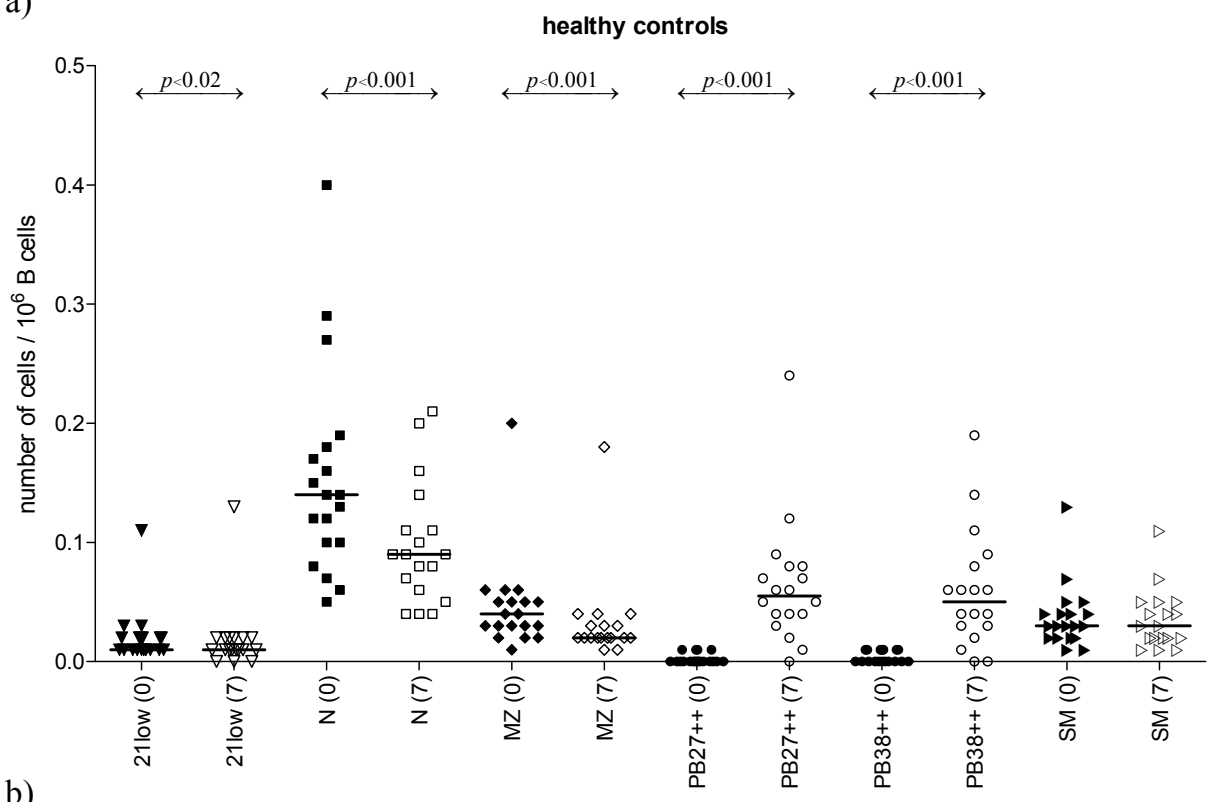

b)

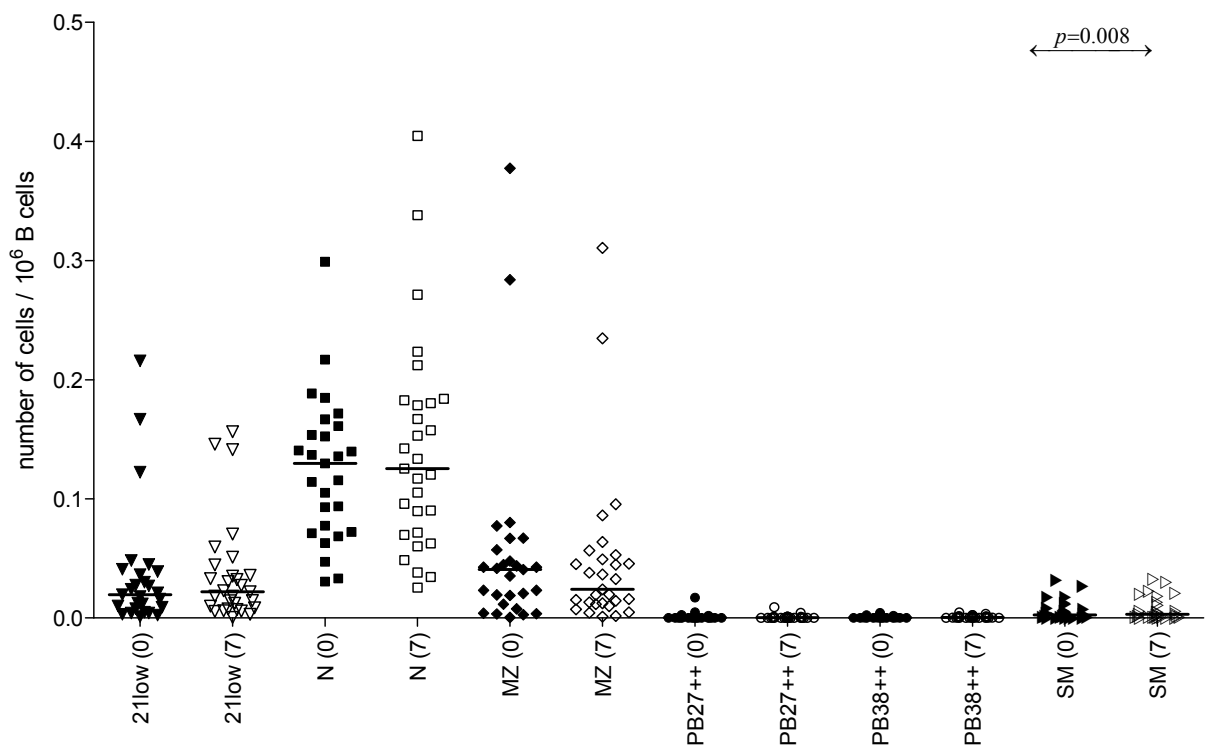

Fig. 2. Changes of absolute numbers of B-cell subpopulations in healthy controls (HC; $\mathrm{n}=19 ; \mathrm{a})$ and CVID patients (CVID; $\mathrm{n}=29 ; \mathrm{b}$ ) before $(0)$ and one week (7) after antigen challenge. $21^{\text {low }}$ (CD21 low $B$ cells), $\mathrm{N}$ (naïve B cells), MZ (marginal zone - like B cells), PB27++ and $\mathrm{PB}^{++}$(plasmablasts), SM (class-switched memory B cells) 


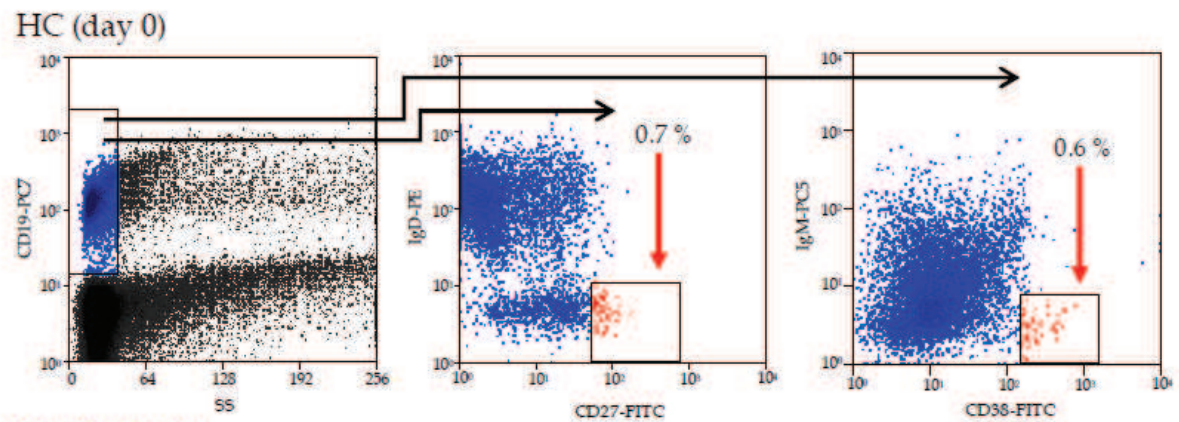

CVID (day 0)

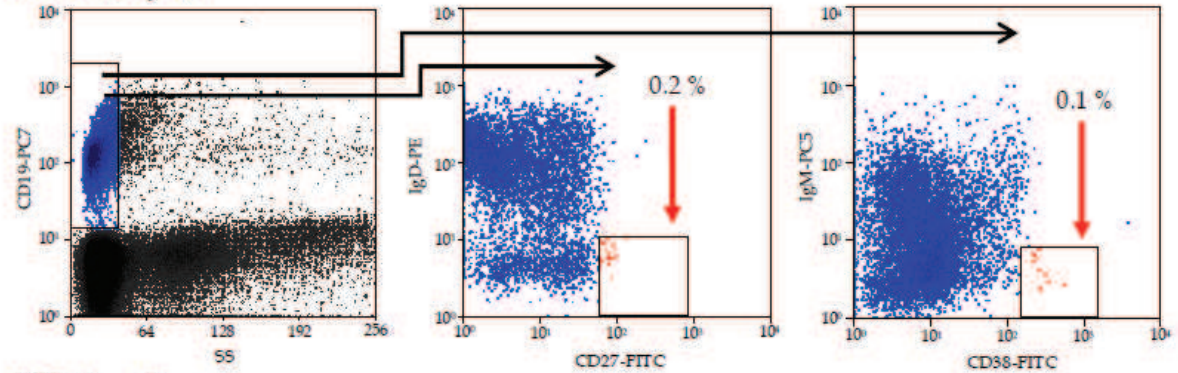

$\mathrm{HC}($ day 7$)$

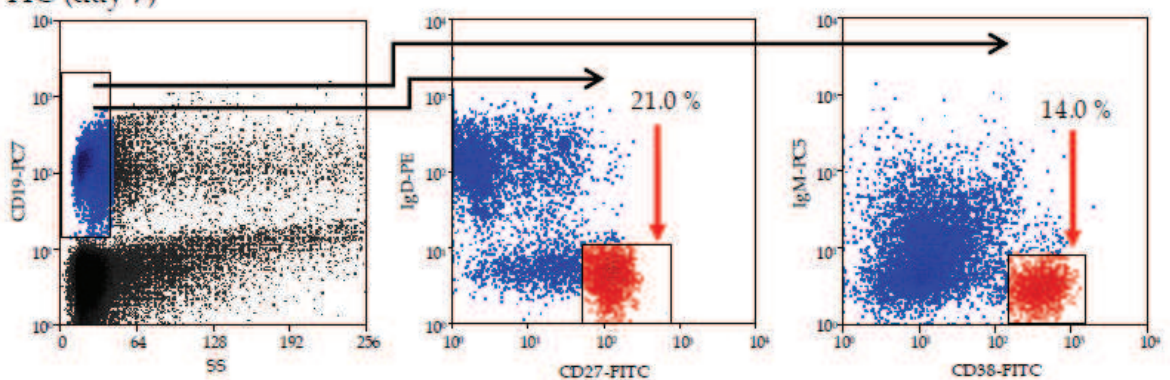

CVID (day 7)
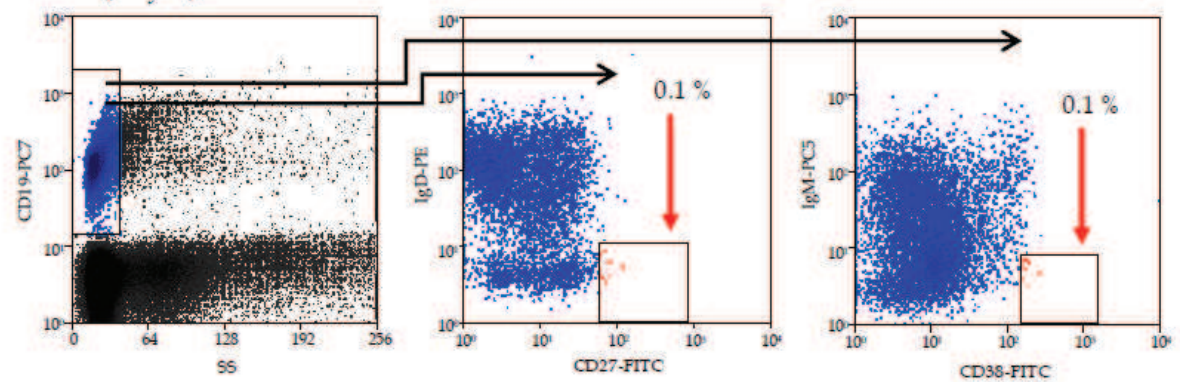

Fig. 3. Development of plasmablasts after vaccination. Plasmablasts (red arrows) were gated from CD19+ B cells (gate in column 1) as IgD-CD27 ${ }^{++}$(column 2) and IgM-CD38 ${ }^{++}$(column 3). The cells were investigated before (day 0 ) and on day 7 after vaccination. HC - healthy control; CVID - CVID patient, $\mathrm{PB} 27^{++}$and $\mathrm{PB} 38^{++}-$plasmablasts 
classifications of CVID (Goldacker et al. 2007; Rezaei et al. 2008). Our group of CVID patients was arranged according to the Freiburg (Warnatz et al. 2002) and EUROclass classification (Wehr et al. 2008). As expected, the majority of our well-defined CVID patients (30/37) failed to mount a specific humoral immune response when analysed by SFCs collected from peripheral blood before and after immunization. The seven CVID patients who responded had much smaller quantities of specific SFC compared to healthy donors. All but one patient with measurable antibody responses belong to group II of the Freiburg classification or EUROclass group $\mathrm{smB}^{+}$which represent those CVID patients with nearly normal numbers of classswitched memory B cells. Patients in these groups are characterized by milder complications of the disease compared to other groups (Alachkar et al. 2006; Wehr et al. 2008).

\subsection{Novel diagnostic tool using flow cytometry in hypogammaglobulinaemic patients with vaccination}

During the last few years a number of studies described differences between B-cell subpopulations of CVID patients and those of healthy volunteers but the kinetics of these changes after encounter with an antigen in vivo (Pinna et al. 2009) has not previously been explored. We investigated the dynamic changes of CD21 low B cells, naïve B cells, marginal zone-like B cells, plasmablasts and switched memory B cells of CVID patients compared to healthy donors (Chovancova et al. 2011). Previous studies showed that memory B cells and plasmablasts have different kinetics in peripheral blood (Stevens et al. 1979). Plasmablasts reach their peak on day 7 after encounter with the antigen in peripheral blood while switched memory B cells showed a marked increase in number on day 14 after antigen challenge (Pinna et al. 2009). The absolute number of naïve B lymphocytes is determined by the generation of new naïve $B$ cells from the bone marrow pool (a slow process) and by acute loss of naïve B lymphocytes via further maturation after antigen encounter (Agenes et al. 2000). Statistically significant up-regulation of naïve B cells and its continued accumulation after antigen challenge in CVID patients indicates disturbed conversion of undifferentiated B cells to more mature B-cell stages in germinal centers. Differentiation is crucially dependent on T-lymphocyte help, suggesting that the basic defects in the majority of CVID patients are not in B cells but in helper T-lymphocytes (Borte et al. 2009; Fischer et al. 1994; Fischer et al. 1996; Thon et al. 1997).

The reduced numbers of switched memory B cells which correlate with clinical complications (Ko et al. 2005; Viallard et al. 2006) and failure to increase the number of plasmablasts after antigen challenge may be explained by insufficient signals from helper $\mathrm{T}$ cells of CVID patients. In previous studies we and others have shown that B cells of CVID patients are able to produce antibodies if they are exposed in vitro to helper T-lymphocyte from healthy donors or to appropriate cytokines (Borte et al. 2009; Fischer et al. 1994; Fischer et al. 1996; Thon et al. 1997), 55. Taubenheim et al. studied B-cell differentiation in lymph nodes from three CVID patients with splenomegaly and found distinct blocks in terminal plasma cell development but normal expression of a key regulator of terminal plasma cell differentiation, Blimp-1 (Taubenheim et al. 2005). Moreover, the clinically important observation that B cells from CVID patients may produce antibodies under certain circumstances correlates with the fact that CVID patients lacking IgA are able to generate IgG anti-IgA antibodies in vivo (Horn et al. 2007). Among our cohort of vaccinated CVID patients, two patients from subgroups Ib and II (Table 2) produced IgG anti-IgA antibodies in low titers although these two patients did not respond to vaccination. 
Our observation that the majority of CVID patients lack antigen specific spot forming B cells and fail to increase circulating plasmablasts following in vivo antigen challenge provides a rapid screening test to demonstrate defective antibody responses in CVID patients, even when on replacement IVIG therapy (Chovancova et al. 2011).

\section{Conclusion and clinical implications}

Identification of circulating plasmablasts after vaccination is a new simple flow based test to assess antibody responses in hypogammaglobulinaemic patients, even if on immunoglobulin (IVIG or SCIG) replacement therapy.

\section{Acknowledgement}

We thank Prof. Dr. Hans D. Ochs for critical discussions. The research leading to these results has received funding from the Ministry of Health of the Czech Republic, Grant no. NR9035-4 and from the European Community's Seventh Framework Programme FP7/20072013 under grant agreement no. 201549 (EURO-PADnet HEALTH-F2-2008-201549).

\section{References}

Agenes, F., Rosado, M. M. \& Freitas, A. A. (2000). Peripheral B cell survival. Cell Mol Life Sci Vol. 57, No. 8-9, (August 2000), pp. 1220-1228.

Alachkar, H., Taubenheim, N., Haeney, M. R., Durandy, A. \& Arkwright, P. D. (2006). Memory switched B cell percentage and not serum immunoglobulin concentration is associated with clinical complications in children and adults with specific antibody deficiency and common variable immunodeficiency. Clin Immunol Vol. 120, No. 3, (September 2006), pp. 310-318.

Borte, S., Pan-Hammarstrom, Q., Liu, C., Sack, U., Borte, M., Wagner, U., Graf, D. \& Hammarstrom, L. (2009). Interleukin-21 restores immunoglobulin production ex vivo in patients with common variable immunodeficiency and selective IgA deficiency. Blood Vol. 114, No. 19, (November 5 2009), pp. 4089-4098.

Bryant, A., Calver, N. C., Toubi, E., Webster, A. D. \& Farrant, J. (1990). Classification of patients with common variable immunodeficiency by B cell secretion of $\operatorname{IgM}$ and IgG in response to anti-IgM and interleukin-2. Clin Immunol Immunopathol Vol. 56, No. 2, (August 1990), pp. 239-248.

Carsetti, R., Rosado, M. M. \& Wardmann, H. (2004). Peripheral development of B cells in mouse and man. Immunol Rev Vol. 197, (February 2004), pp. 179-191.

Castigli, E., Wilson, S. A., Garibyan, L., Rachid, R., Bonilla, F., Schneider, L. \& Geha, R. S. (2005). TACI is mutant in common variable immunodeficiency and IgA deficiency. Nat Genet Vol. 37, No. 8, (August 2005), pp. 829-834.

Chapel, H., Lucas, M., Lee, M., Bjorkander, J., Webster, D., Grimbacher, B., Fieschi, C., Thon, V., Abedi, M. R. \& Hammarstrom, L. (2008). Common variable immunodeficiency disorders: division into distinct clinical phenotypes. Blood Vol. 112, No. 2, (July 2008), pp. 277-286.

Chovancova, Z., Vlkova, M., Litzman, J., Lokaj, J. \& Thon, V. (2011). Antibody forming cells and plasmablasts in peripheral blood in CVID patients after vaccination. Vaccine Vol. 29, No. 24, (May 2011), pp. 4142-4150. 
Conley, M. E., Notarangelo, L. D. \& Etzioni, A. (1999). Diagnostic criteria for primary immunodeficiencies. Representing PAGID (Pan-American Group for Immunodeficiency) and ESID (European Society for Immunodeficiencies). Clin Immunol Vol. 93, No. 3, (December 1999), pp. 190-197.

Cunningham-Rundles, C. \& Bodian, C. (1999). Common variable immunodeficiency: clinical and immunological features of 248 patients. Clin Immunol Vol. 92, No. 1, (July 1999), pp. 34-48.

Czerkinsky, C. C., Nilsson, L. A., Nygren, H., Ouchterlony, O. \& Tarkowski, A. (1983). A solid-phase enzyme-linked immunospot (ELISPOT) assay for enumeration of specific antibody-secreting cells. J Immunol Methods Vol. 65, No. 1-2, (December 16 1983), pp. 109-121.

Farrington, M., Grosmaire, L. S., Nonoyama, S., Fischer, S. H., Hollenbaugh, D., Ledbetter, J. A., Noelle, R. J., Aruffo, A. \& Ochs, H. D. (1994). CD40 ligand expression is defective in a subset of patients with common variable immunodeficiency. Proc Natl Acad Sci U S A Vol. 91, No. 3, (February 1994), pp. 1099-1103.

Ferry, B. L., Jones, J., Bateman, E. A., Woodham, N., Warnatz, K., Schlesier, M., Misbah, S. A., Peter, H. H. \& Chapel, H. M. (2005). Measurement of peripheral B cell subpopulations in common variable immunodeficiency (CVID) using a whole blood method. Clin Exp Immunol Vol. 140, No. 3, (June 2005),pp. 532-539.

Fischer, M. B., Hauber, I., Eggenbauer, H., Thon, V., Vogel, E., Schaffer, E., Lokaj, J., Litzman, J., Wolf, H. M., Mannhalter, J. W. \& et al. (1994). A defect in the early phase of T-cell receptor-mediated T-cell activation in patients with common variable immunodeficiency. Blood Vol. 84, No. 12, (December 15 1994), pp. 42344241.

Fischer, M. B., Hauber, I., Wolf, H. M., Vogel, E., Mannhalter, J. W. \& Eibl, M. M. (1994). Impaired TCR signal transduction, but normal antigen presentation, in a patient with common variable immunodeficiency. Br J Haematol Vol. 88, No. 3, (November 1994), pp. 520-526.

Fischer, M. B., Wolf, H. M., Hauber, I., Eggenbauer, H., Thon, V., Sasgary, M. \& Eibl, M. M. (1996). Activation via the antigen receptor is impaired in T cells, but not in B cells from patients with common variable immunodeficiency. Eur J Immunol Vol. 26, No. 1, (January 1996), pp. 231-237.

Funauchi, M., Farrant, J., Moreno, C. \& Webster, A. D. (1995). Defects in antigen-driven lymphocyte responses in common variable immunodeficiency (CVID) are due to a reduction in the number of antigen-specific CD4+ T cells. Clin Exp Immunol Vol. 101, No. 1, (July 1995), pp. 82-88.

Giovannetti, A., Pierdominici, M., Mazzetta, F., Marziali, M., Renzi, C., Mileo, A. M., De Felice, M., Mora, B., Esposito, A., Carello, R., Pizzuti, A., Paggi, M. G., Paganelli, R., Malorni, W. \& Aiuti, F. (2007). Unravelling the complexity of T cell abnormalities in common variable immunodeficiency. J Immunol Vol. 178, No. 6, (March 15 2007), pp. 3932-3943.

Goldacker, S., Draeger, R., Warnatz, K., Huzly, D., Salzer, U., Thiel, J., Eibel, H., Schlesier, M. \& Peter, H. H. (2007). Active vaccination in patients with common variable immunodeficiency (CVID). Clin Immunol Vol. 124, No. 3, (September 2007), pp. 294303. 
Grimbacher, B., Hutloff, A., Schlesier, M., Glocker, E., Warnatz, K., Drager, R., Eibel, H., Fischer, B., Schaffer, A. A., Mages, H. W., Kroczek, R. A. \& Peter, H. H. (2003). Homozygous loss of ICOS is associated with adult-onset common variable immunodeficiency. Nat Immunol Vol. 4, No. 3, (March 2003), pp. 261-268.

Horn, J., Manguiat, A., Berglund, L. J., Knerr, V., Tahami, F., Grimbacher, B. \& Fulcher, D. A. (2009). Decrease in phenotypic regulatory $\mathrm{T}$ cells in subsets of patients with common variable immunodeficiency. Clin Exp Immunol Vol. 156, No. 3, (June 2009), pp. 446-454.

Horn, J., Thon, V., Bartonkova, D., Salzer, U., Warnatz, K., Schlesier, M., Peter, H. H. \& Grimbacher, B. (2007). Anti-IgA antibodies in common variable immunodeficiency (CVID): diagnostic workup and therapeutic strategy. Clin Immunol Vol. 122, No. 2, (February 2007), pp. 156-162.

Klein, U., Kuppers, R. \& Rajewsky, K. (1997). Evidence for a large compartment of IgMexpressing memory B cells in humans. Blood Vol. 89, No. 4, (February 1997), pp. 1288-1298.

Ko, J., Radigan, L. \& Cunningham-Rundles, C. (2005). Immune competence and switched memory B cells in common variable immunodeficiency. Clin Immunol Vol. 116, No. 1, (July 2005), pp. 37-41.

Kodo, H., Gale, R. P. \& Saxon, A. (1984). Antibody synthesis by bone marrow cells in vitro following primary and booster tetanus toxoid immunization in humans. J Clin Invest Vol. 73, No. 5, (May 1984), pp. 1377-1384.

Litzman, J., Vlkova, M., Pikulova, Z., Stikarovska, D. \& Lokaj, J. (2007). T and B lymphocyte subpopulations and activation/differentiation markers in patients with selective IgA deficiency. Clin Exp Immunol Vol. 147, No. 2, (February 2007), pp. 249-254.

Mohammadi, J., Liu, C., Aghamohammadi, A., Bergbreiter, A., Du, L., Lu, J., Rezaei, N., Amirzargar, A. A., Moin, M., Salzer, U., Pan-Hammarstrom, Q. \& Hammarstrom, L. (2009). Novel mutations in TACI (TNFRSF13B) causing common variable immunodeficiency. J Clin Immunol Vol. 29, No. 6, (November 2009), pp. 777-785.

Mouillot, G., Carmagnat, M., Gerard, L., Garnier, J. L., Fieschi, C., Vince, N., Karlin, L., Viallard, J. F., Jaussaud, R., Boileau, J., Donadieu, J., Gardembas, M., Schleinitz, N., Suarez, F., Hachulla, E., Delavigne, K., Morisset, M., Jacquot, S., Just, N., Galicier, L., Charron, D., Debre, P., Oksenhendler, E. \& Rabian, C. B-Cell and T-Cell Phenotypes in CVID Patients Correlate with the Clinical Phenotype of the Disease. J Clin Immunol Vol. 30, No. 5, (May 2010), pp. 746-755.

Ochs, H. D., Davis, S. D. \& Wedgwood, R. J. (1971). Immunologic responses to bacteriophage phi-X 174 in immunodeficiency diseases. J Clin Invest Vol. 50, No. 12, (Dec 1971) pp. 2559-2568.

Pinna, D., Corti, D., Jarrossay, D., Sallusto, F. \& Lanzavecchia, A. (2009). Clonal dissection of the human memory B-cell repertoire following infection and vaccination. Eur J Immunol Vol. 39, No. 5, (May 2009), pp. 1260-1270.

Piqueras, B., Lavenu-Bombled, C., Galicier, L., Bergeron-van der Cruyssen, F., Mouthon, L., Chevret, S., Debre, P., Schmitt, C. \& Oksenhendler, E. (2003). Common variable immunodeficiency patient classification based on impaired B cell memory differentiation correlates with clinical aspects. J Clin Immunol Vol. 23, No. 5, (September 2003), pp. 385-400. 
Rakhmanov, M., Keller, B., Gutenberger, S., Foerster, C., Hoenig, M., Driessen, G., van der Burg, M., van Dongen, J. J., Wiech, E., Visentini, M., Quinti, I., Prasse, A., Voelxen, N., Salzer, U., Goldacker, S., Fisch, P., Eibel, H., Schwarz, K., Peter, H. H. \& Warnatz, K. (2009). Circulating CD21low B cells in common variable immunodeficiency resemble tissue homing, innate-like B cells. Proc Natl Acad Sci U $S$ A Vol. 106, No. 32, (August 2009), pp. 13451-13456.

Rezaei, N., Aghamohammadi, A. \& Read, R. C. (2008). Response to polysaccharide vaccination amongst pediatric patients with common variable immunodeficiency correlates with clinical disease. Iran J Allergy Asthma Immunol Vol. 7, No. 4, (December 2008), pp. 231-234.

Rezaei, N., Aghamohammadi, A., Siadat, S. D., Moin, M., Pourpak, Z., Nejati, M., Ahmadi, H., Kamali, S., Norouzian, D., Tabaraei, B. \& Read, R. C. (2008). Serum bactericidal antibody responses to meningococcal polysaccharide vaccination as a basis for clinical classification of common variable immunodeficiency. Clin Vaccine Immunol Vol. 15, No. 4, (April 2008), pp. 607-611.

Rezaei, N., Siadat, S. D., Aghamohammadi, A., Moin, M., Pourpak, Z., Norouzian, D., Mobarakeh, J. I., Aghasadeghi, M. R., Nejati, M. \& Read, R. C. Serum bactericidal antibody response 1 year after meningococcal polysaccharide vaccination of patients with common variable immunodeficiency. Clin Vaccine Immunol Vol. 17, No. 4, (April 2010), pp. 524-528.

Salzer, U., Chapel, H. M., Webster, A. D., Pan-Hammarstrom, Q., Schmitt-Graeff, A., Schlesier, M., Peter, H. H., Rockstroh, J. K., Schneider, P., Schaffer, A. A., Hammarstrom, L. \& Grimbacher, B. (2005). Mutations in TNFRSF13B encoding TACI are associated with common variable immunodeficiency in humans. Nat Genet Vol. 37, No. 8, (August 2005), pp. 820-828.

Salzer, U., Maul-Pavicic, A., Cunningham-Rundles, C., Urschel, S., Belohradsky, B. H., Litzman, J., Holm, A., Franco, J. L., Plebani, A., Hammarstrom, L., Skrabl, A., Schwinger, W. \& Grimbacher, B. (2004). ICOS deficiency in patients with common variable immunodeficiency. Clin Immunol Vol. 113, No. 3, (December 2004), pp. 234240.

Sanchez-Ramon, S., Radigan, L., Yu, J. E., Bard, S. \& Cunningham-Rundles, C. (2008). Memory B cells in common variable immunodeficiency: clinical associations and sex differences. Clin Immunol Vol. 128, No. 3, (September 2008), pp. 314-321.

Sekine, H., Ferreira, R. C., Pan-Hammarstrom, Q., Graham, R. R., Ziemba, B., de Vries, S. S., Liu, J., Hippen, K., Koeuth, T., Ortmann, W., Iwahori, A., Elliott, M. K., Offer, S., Skon, C., Du, L., Novitzke, J., Lee, A. T., Zhao, N., Tompkins, J. D., Altshuler, D., Gregersen, P. K., Cunningham-Rundles, C., Harris, R. S., Her, C., Nelson, D. L., Hammarstrom, L., Gilkeson, G. S. \& Behrens, T. W. (2007). Role for Msh5 in the regulation of Ig class switch recombination. Proc Natl Acad Sci U S A Vol. 104, No. 17, (April 2007), pp. 7193-7198.

Shi, Y., Agematsu, K., Ochs, H. D. \& Sugane, K. (2003). Functional analysis of human memory B-cell subpopulations: IgD+CD27+ B cells are crucial in secondary immune response by producing high affinity IgM. Clin Immunol Vol. 108, No. 2, (August 2003), pp. 128-137. 
Schaffer, A. A., Salzer, U., Hammarstrom, L. \& Grimbacher, B. (2007). Deconstructing common variable immunodeficiency by genetic analysis. Curr Opin Genet Dev Vol. 17, No. 3, (June 2007), pp. 201-212.

Stevens, R. H., Macy, E., Morrow, C. \& Saxon, A. (1979). Characterization of a circulating subpopulation of spontaneous antitetanus toxoid antibody producing B cells following in vivo booster immunization. J Immunol Vol. 122, No. 6, (June 1979), pp. 2498-2504.

Tangye, S. G. \& Tarlinton, D. M. (2009). Memory B cells: effectors of long-lived immune responses. Eur J Immunol Vol. 39, No. 8, (Aug 2009) pp. 2065-2075.

Taubenheim, N., von Hornung, M., Durandy, A., Warnatz, K., Corcoran, L., Peter, H. H. \& Eibel, H. (2005). Defined blocks in terminal plasma cell differentiation of common variable immunodeficiency patients. J Immunol Vol. 175, No. 8, (October 2005), pp. 5498-5503.

Thiele, C. J., Morrow, C. D. \& Stevens, R. H. (1982). Human IgA antibody and immunoglobulin production after in vivo tetanus toxoid immunization: size and surface membrane phenotype analysis. J Clin Immunol Vol. 2, No. 4, (October 1982), pp. 327-334.

Thon, V., Wolf, H. M., Sasgary, M., Litzman, J., Samstag, A., Hauber, I., Lokaj, J. \& Eibl, M. M. (1997). Defective integration of activating signals derived from the $T$ cell receptor (TCR) and costimulatory molecules in both CD4+ and CD8+ T lymphocytes of common variable immunodeficiency (CVID) patients. Clin Exp Immunol Vol. 110, No. 2, (November 1997), pp. 174-181.

van Zelm, M. C., Reisli, I., van der Burg, M., Castano, D., van Noesel, C. J., van Tol, M. J., Woellner, C., Grimbacher, B., Patino, P. J., van Dongen, J. J. \& Franco, J. L. (2006). An antibody-deficiency syndrome due to mutations in the CD19 gene. N Engl J Med Vol. 354, No. 18, (May 2006), pp. 1901-1912.

van Zelm, M. C., Smet, J., Adams, B., Mascart, F., Schandene, L., Janssen, F., Ferster, A., Kuo, C. C., Levy, S., van Dongen, J. J. \& van der Burg, M. (2010). CD81 gene defect in humans disrupts CD19 complex formation and leads to antibody deficiency. J Clin Invest Vol. 2010, No. 120(4), (April 2010), pp. 1265-1274.

Viallard, J. F., Blanco, P., Andre, M., Etienne, G., Liferman, F., Neau, D., Vidal, E., Moreau, J. F. \& Pellegrin, J. L. (2006). CD8+HLA-DR+ T lymphocytes are increased in common variable immunodeficiency patients with impaired memory B-cell differentiation. Clin Immunol Vol. 119, No. 1, (April 2006), pp. 51-58.

Warnatz, K., Denz, A., Drager, R., Braun, M., Groth, C., Wolff-Vorbeck, G., Eibel, H., Schlesier, M. \& Peter, H. H. (2002). Severe deficiency of switched memory B cells $(\mathrm{CD} 27(+) \operatorname{IgM}(-) \operatorname{IgD}(-))$ in subgroups of patients with common variable immunodeficiency: a new approach to classify a heterogeneous disease. Blood Vol. 99, No. 5, (March 2002), pp. 1544-1551.

Warnatz, K. \& Schlesier, M. (2008). Flowcytometric phenotyping of common variable immunodeficiency. Cytometry B Clin Cytom Vol. 74, No. 5, (September 2008), pp. 261-271.

Wehr, C., Kivioja, T., Schmitt, C., Ferry, B., Witte, T., Eren, E., Vlkova, M., Hernandez, M., Detkova, D., Bos, P. R., Poerksen, G., von Bernuth, H., Baumann, U., Goldacker, S., Gutenberger, S., Schlesier, M., Bergeron-van der Cruyssen, F., Le Garff, M., Debre, P., Jacobs, R., Jones, J., Bateman, E., Litzman, J., van Hagen, P. M., Plebani, A., 
Schmidt, R. E., Thon, V., Quinti, I., Espanol, T., Webster, A. D., Chapel, H., Vihinen, M., Oksenhendler, E., Peter, H. H. \& Warnatz, K. (2008). The EUROclass trial: defining subgroups in common variable immunodeficiency. Blood Vol. 111, No. 1, (January 2008), pp. 77-85.

Weller, S., Braun, M. C., Tan, B. K., Rosenwald, A., Cordier, C., Conley, M. E., Plebani, A., Kumararatne, D. S., Bonnet, D., Tournilhac, O., Tchernia, G., Steiniger, B., Staudt, L. M., Casanova, J. L., Reynaud, C. A. \& Weill, J. C. (2004). Human blood IgM "memory" B cells are circulating splenic marginal zone B cells harboring a prediversified immunoglobulin repertoire. Blood Vol. 104, No. 12, (December 2004), pp. 3647-3654. 


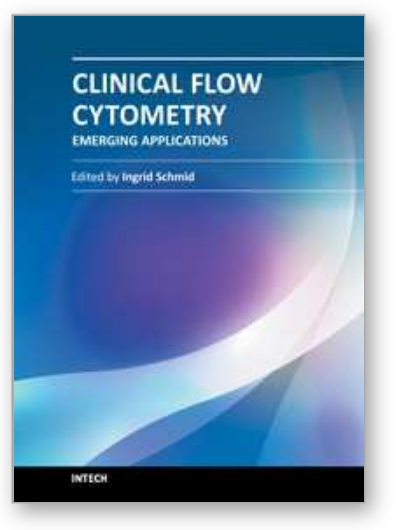

\author{
Clinical Flow Cytometry - Emerging Applications \\ Edited by M.Sc. Ingrid Schmid
}

ISBN 978-953-51-0575-6

Hard cover, 204 pages

Publisher InTech

Published online 16, May, 2012

Published in print edition May, 2012

"Clinical Flow Cytometry - Emerging Applications" contains a collection of reviews and original papers that illustrate the relevance of flow cytometry for the study of specific diseases and clinical evaluations. The chapters have been contributed by authors from a wide variety of countries showing the broad application and importance of this technology in medicine. Examples include chapters on autoimmune disease, cancer, and the evaluation of new drugs. The book is intended to give newcomers a helpful introduction, but also to provide experienced flow cytometrists with novel insights and a better understanding of clinical cytometry.

\title{
How to reference
}

In order to correctly reference this scholarly work, feel free to copy and paste the following:

Vojtech Thon, Marcela Vlkova, Zita Chovancova, Jiri Litzman and Jindrich Lokaj (2012). Flow Based Enumeration of Plasmablasts in Peripheral Blood After Vaccination as a Novel Diagnostic Marker for Assessing Antibody Responses in Patients with Hypogammaglobulinaemia, Clinical Flow Cytometry - Emerging Applications, M.Sc. Ingrid Schmid (Ed.), ISBN: 978-953-51-0575-6, InTech, Available from: http://www.intechopen.com/books/clinical-flow-cytometry-emerging-applications/flow-based-enumeration-ofplasmablasts-in-peripheral-blood-after-vaccination-as-a-novel-diagnostic-m

\section{INTECH}

open science | open minds

\section{InTech Europe}

University Campus STeP Ri

Slavka Krautzeka 83/A

51000 Rijeka, Croatia

Phone: +385 (51) 770447

Fax: +385 (51) 686166

www.intechopen.com

\section{InTech China}

Unit 405, Office Block, Hotel Equatorial Shanghai

No.65, Yan An Road (West), Shanghai, 200040, China

中国上海市延安西路65号上海国际贵都大饭店办公楼 405 单元

Phone: +86-21-62489820

Fax: $+86-21-62489821$ 
(C) 2012 The Author(s). Licensee IntechOpen. This is an open access article distributed under the terms of the Creative Commons Attribution 3.0 License, which permits unrestricted use, distribution, and reproduction in any medium, provided the original work is properly cited. 